\title{
FLOCCULATION OF FINE FLUORITE PARTICLES WITH CORYNEBACTERIUM XEROSIS
}

\author{
Sandra R. Haas ${ }^{1}$; Fábio R. Nascimento ${ }^{1}$; Ivo André H. Schneider ${ }^{1 *}$; Christine Gaylarde ${ }^{2}$ \\ ${ }^{1}$ FEAR, Universidade de Passo Fundo, Passo Fundo, RS, Brasil. ${ }^{2}$ MIRCEN, Departamento de Solos, \\ Universidade Federal do Rio Grande do Sul, Porto Alegre, RS, Brasil
}

Submitted: November 11, 1998; Approved: May 21, 1999.

\begin{abstract}
The treatment of fine particles dispersed in liquids is common in several industries and especially important in mineral processing. The efficiency of settling operations can be substantially increased by flocculation. The aim of this work was to study the flocculation of fine fluorite particles by the bacterium Corynebacterium xerosis. Flocculation tests, microelectrophoresis measurements and optical microscopy were used to evaluate flocculation. The results showed that $C$. xerosis cells adhere to the fluorite surfaces promoting the aggregation of the particles. High quality flocs can be obtained rapidly at $\mathrm{pH} 7.0$ using a cell concentration of $40 \mathrm{mg} / \mathrm{l}$, considerably lower than previously reported in the literature. The results are discussed with reference to the surface characteristics of the mineral and of the microorganism.
\end{abstract}

Key words: adhesion, Corynebacterium xerosis, flocculation, fluorite.

\section{INTRODUCTION}

At various stages during the processing of minerals it is necessary to separate the aqueous suspensions into their component solid and liquid phases. Typical examples of this are thickening of flotation concentrates, recovery of pregnant leach liquors, and dewatering of tailings. In many cases, the mineral particles settle out of suspension very slowly, so that the liquid-solid separation is slow and incomplete.

The efficiency of such gravity settling operations can be substantially increased by aggregation of the mineral particles. Methods currently used for aggregation and settling of finely divided solids in slurries include $\mathrm{pH}$ adjustment, increasing ionic strength, introduction of inorganic coagulants such as aluminum and ferric salts, and introduction of organic flocculants such as starch and long chain synthetic flocculants $(10,15,16)$. These methods, in addition to increasing costs, can also lead to the release of polluting waste materials.

Finely divided mineral particles can also be flocculated by microorganisms. An isolate of Arthrobacter has been shown to promote the settling of fines in manganese ore washings (5). The bacterium Mycobacterium phlei $(7,14)$ and the yeast Candida parapsilosis $(12,13)$ improved settling rates in mineral suspensions, but flocculation was not as good as that obtained with commercial long chain flocculants. Most microorganisms adhere to solid surfaces if the charge and hydrophobic interactions between the cells and the solid surface are favorable, but do not always promote flocculation of mineral

\footnotetext{
* Corresponding author. Mailing address: FEAR, Universidade de Passo Fundo, Campus, Bairro São José, CEP 99001-970, Passo Fundo, RS, Brasil. Fax: (+554)316-8211. E-mail ivoandre@upf.tche.br
} 
particles. The mechanism of this flocculation appears primarily to be cell adhesion and bridging between the particles.

Van Loosdrecht et al. $(17,18)$ showed that cells of M. phlei and Corynebacterium xerosis were highly hydrophobic and negatively charged. Since previous work has shown that the former microorganism does not effectively promote flocculation of fluorite (8), we investigated the potential of the latter, C.xerosis, to flocculate fine fluorite particles. The effect of settling time, cell concentration, and $\mathrm{pH}$ of the suspension on solids settling was studied. The results are discussed in terms of the surface properties of the mineral and of the microorganism.

\section{MATERIALS AND METHODS}

\section{Fluorite}

Fluorite crystals $\left(99 \% \mathrm{CaF}_{2}\right)$ were obtained from a mining company (Criciúma - Santa Catarina, Brazil). The crystals were ground in a laboratory mill. The particle size distribution of the sample used for flocculation tests was determined by laser difraction in a Malvern Particle Size Analyzer Model 3601 (Table 1).

Table 1. Particle size distribution of fluorite.

\begin{tabular}{cc}
\hline Size range & Weight $(\%)$ \\
\hline larger than $40 \mu \mathrm{m}$ & 3 \\
$40-30 \mu \mathrm{m}$ & 9 \\
$30-20 \mu \mathrm{m}$ & 18 \\
$20-10 \mu \mathrm{m}$ & 29 \\
$10-5 \mu \mathrm{m}$ & 18 \\
$5-1 \mu \mathrm{m}$ & 21 \\
smaller than $1 \mu \mathrm{m}$ & 2 \\
\hline
\end{tabular}

\section{Microorganisms}

The bacterium Corynebacterium xerosis, from Caroline Biological Supply Company - USA, was grown for 72 hours in nutrient broth. Cultures were produced in $300 \mathrm{ml}$ flasks, continuously shaken at $37^{\circ} \mathrm{C}$. Cells were harvested by centrifugation, washed twice in distilled water and finally suspended in water to give a $2 \mathrm{~g} / 1$ suspension. This stock cell solution was kept at $5^{\circ} \mathrm{C}$ and used in flocculation studies within 48 hours, either neat, or at various dilutions.

\section{Flocculation tests}

Flocculation studies were carried out using a standard "Jar Test" apparatus. Settling tests were performed by preparing $1000 \mathrm{ml}$ suspensions containing $10 \mathrm{~g} / \mathrm{l}$ of fluorite. The $\mathrm{pH}$ of the medium was adjusted as required and the microorganisms added to the mineral suspension. The suspensions were mixed by stirring for $1 \mathrm{~min}$ at $250 \mathrm{rpm}$ to promote a uniform distribution of the cells. The stirrer speed was reduced to $50 \mathrm{rpm}$ for $2 \mathrm{~min}$, to create low shear conditions and allow floc formation. Particles were then allowed to settle under gravity and samples were withdrawn at set time intervals from $10 \mathrm{~cm}$ below the water surface.

The flocculation efficiency was evaluated by the following parameters:

- naked eye and microscope observation of floc quality;

- residual turbidity in nephelometric units of turbidity (NTU);

- solids removal from water.

The solids concentration was determined gravimetrically. The solids removal percentage (or flocculation efficiency) was calculated using the relationship.

$$
\mathrm{E}(\%)=100 \times \frac{(\mathrm{Ci}-\mathrm{Cf})}{\mathrm{Ci}}
$$

where: $\mathrm{Ci}=$ initial concentration of solids $\mathrm{Cf}=$ concentration of solids after time $\mathrm{t}$

\section{Zeta potential measurements}

The electrokinetic properties were studied as a function of $\mathrm{pH}$ using a Rank Brothers Ltd microelectrophoresis apparatus. C. xerosis cells and fluorite particles were suspended in water containing $1 \times 10^{-3} \mathrm{MNaNO}_{3}$ and the $\mathrm{pH}$ was adjusted by addition of $\mathrm{NaOH}$ and $\mathrm{HNO}_{3}$. For each $\mathrm{pH}$ value 20 readings were taken and averaged. The zeta potential was calculated from electrophoretic mobility using the Smoluchowsky equation (9).

\section{RESULTS}

Fig. 1 shows photomicrographs demonstrating the flocculation of fluorite by $C$. xerosis. Fig. 1a shows dispersed fluorite particles in the absence of the microorganisms. In the presence of $C$. xerosis cells, particles are agglomerated (Fig. 1b). These fluorite/cell aggregates settle very rapidly in water allowing an almost complete solids removal and a high clarification of the water. 

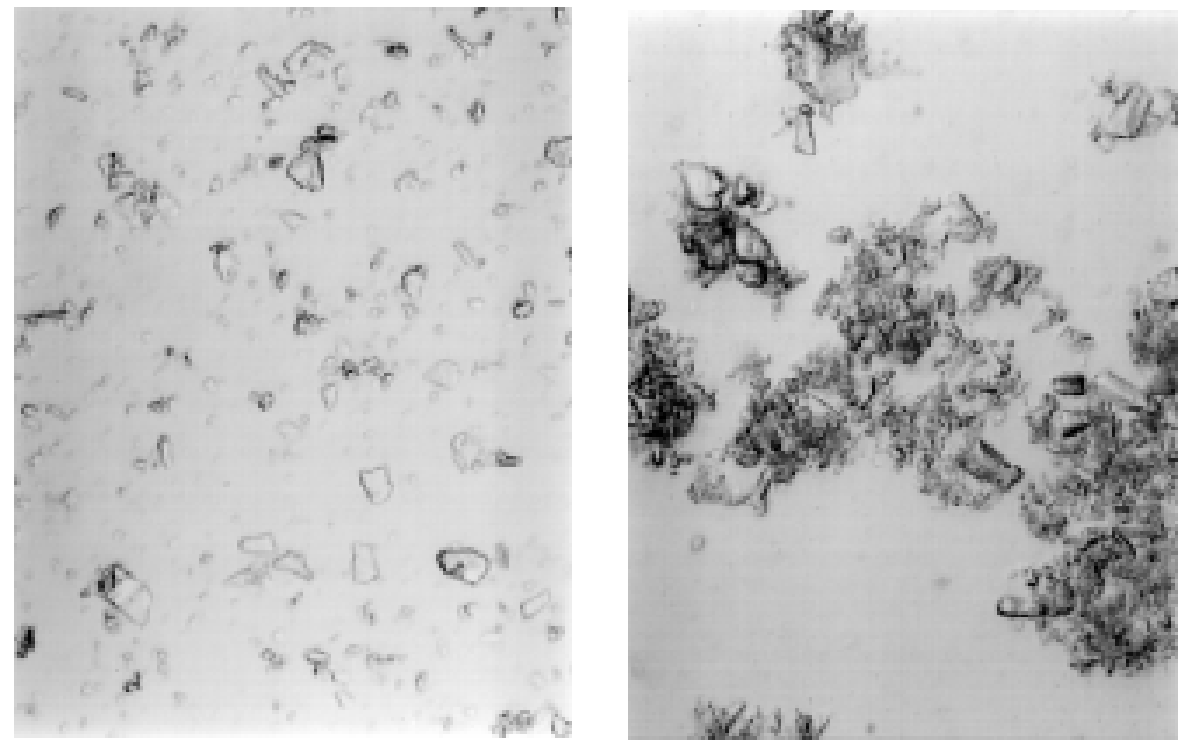

Figure 1. Photomicrographs of fluorite particles suspended in water (a) and aggregated in the presence of Corynebacterium xerosis (b). Magnification 100x.

The effect of settling time on flocculation efficiency in the presence of $40 \mathrm{mg} / 1$ C. xerosis cells at $\mathrm{pH} 7.0$ is shown in Fig. 2. The result is compared to a plot obtained in the absence of flocculant. In the presence of bacteria, near maximum flocculation is obtained within $30 \mathrm{~s}$ after the beginning of settling. The same test procedure was used to evaluate the effect of settling time on residual turbidity, which

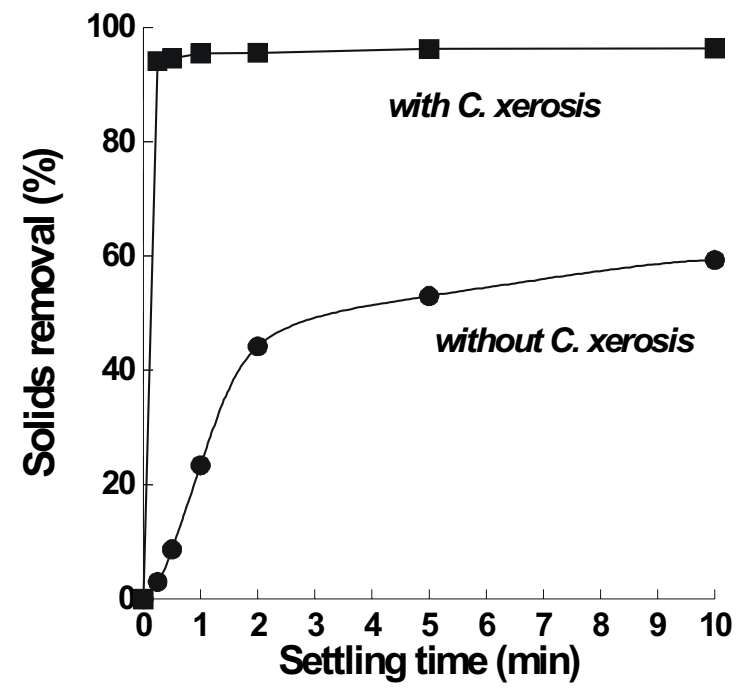

Figure 2. Solids removal efficiency of fluorite suspensions as a function of settling time in the presence or absence of $40 \mathrm{mg} / \mathrm{l}$ of Corynebacterium xerosis (pH 7.0 +/- 0.2). was decreased from $130 \mathrm{NTU}$ to $20 \mathrm{NTU}$ in approximately $5 \mathrm{~min}$ in the presence of $C$. xerosis (Fig. 3).

Fig. 4 shows the flocculation results as a function of cell concentration. Good flocculation is obtained at a microorganism dosage of $20 \mathrm{mg} / \mathrm{l}$ and maximum flocculation at $40 \mathrm{mg} / \mathrm{l}$. About $96 \%$ of the solids present in the suspension were removed

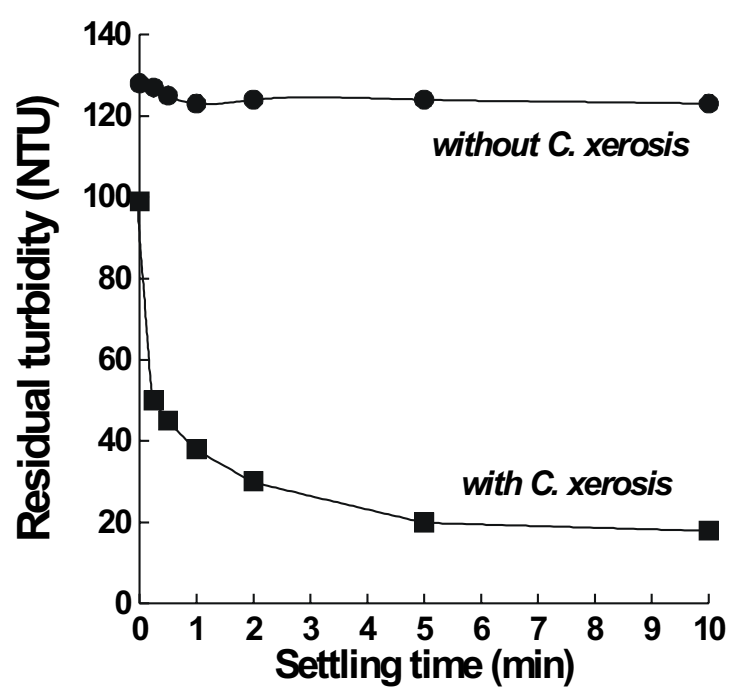

Figure 3. Residual turbidity of fluorite suspension as a function of settling time in the presence or absence of $40 \mathrm{mg} / 1$ of Corynebacterium xerosis ( $\mathrm{pH} 7.0$ +/- 0.2). 
in a settling time of $1 \mathrm{~min}$. Higher concentrations than $40 \mathrm{mg} / \mathrm{l}$ did not produce any improvement in floc quality.

Fig. 5 represents flocculation efficiency as a function of $\mathrm{pH}$. Also shown are data for fluorite flocculation in the absence of microorganisms. At the bacterial cell concentration used, the suspensions were readily flocculated at $\mathrm{pH}$ values of $4.0-9.0$, with an optimum $\mathrm{pH}$ of around 7.0.

Fig. 6 displays the zeta potential of $C$. xerosis cells and of fluorite particles as a function of $\mathrm{pH}$. The C. xerosis cells had an isoelectric point at $\mathrm{pH}$ 2.0 while the isoelectric point of fluorite was near $\mathrm{pH} 10.0$. Negatively charged organisms should ready adhere to the positively charged fluorite at neutral $\mathrm{pH}$ values. At $\mathrm{pH} 7.0$, which gave best flocculation results, the $C$. xerosis cells have a zeta potential of $-30 \mathrm{mV}$ and fluorite particles of about $+60 \mathrm{mV}$.

\section{DISCUSSION}

The experimental data indicate that $C$. xerosis cells adhere to fluorite particles and promote flocculation of fine fluorite suspensions over a range of $\mathrm{pH}$ values. The quality of the flocs obtained are comparable to those produced with long chain polymers. The flocs are very "tight" and dense and contain little water. The flocculation occurs rapidly, within $1 \mathrm{~min}$., showing that these bacteria are more

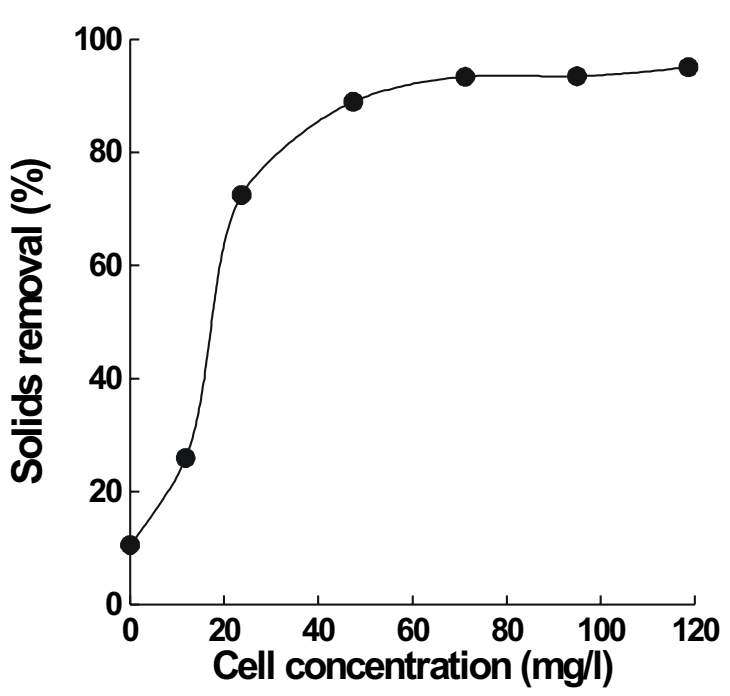

Figure 4. Solids removal efficiency of fluorite suspensions as a function of Corynebacterium xerosis cells ( $\mathrm{pH} 7.0+/-0.2,1 \mathrm{~min}$ settling time). efficient than the Arthrobacter species used by Deshpande (5) for clearing manganese mining wastewaters, which required a minimum of $30 \mathrm{~min}$ settling time.

The mechanism of flocculation has been discussed elsewhere and primarily occurs by cell bridging $(7,14)$. This mechanism is specially efficient in systems where the microorganism is smaller or of

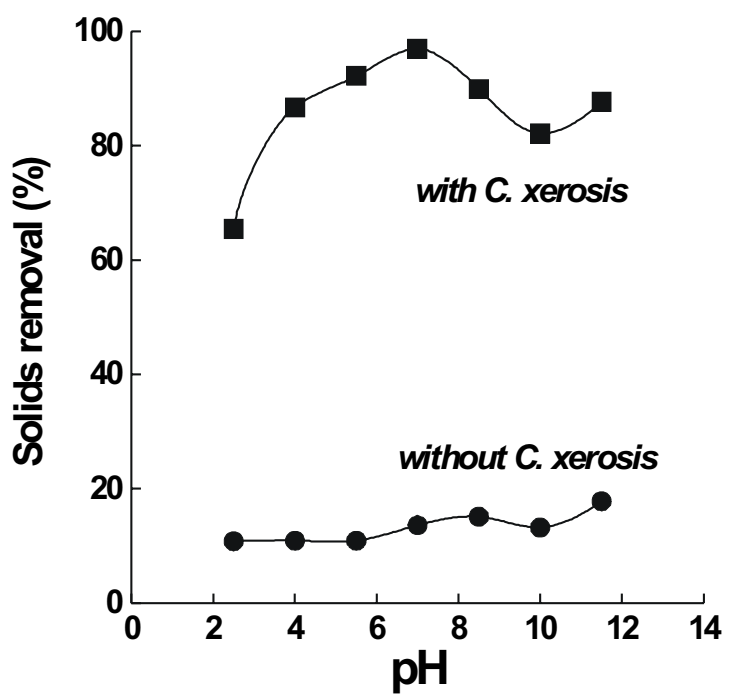

Figure 5. Solids removal efficiency of fluorite suspensions as a function of $\mathrm{pH}$ in the presence or absence of $40 \mathrm{mg} / 1$ of Corynebacterium xerosis cells ( 1 min settling time).

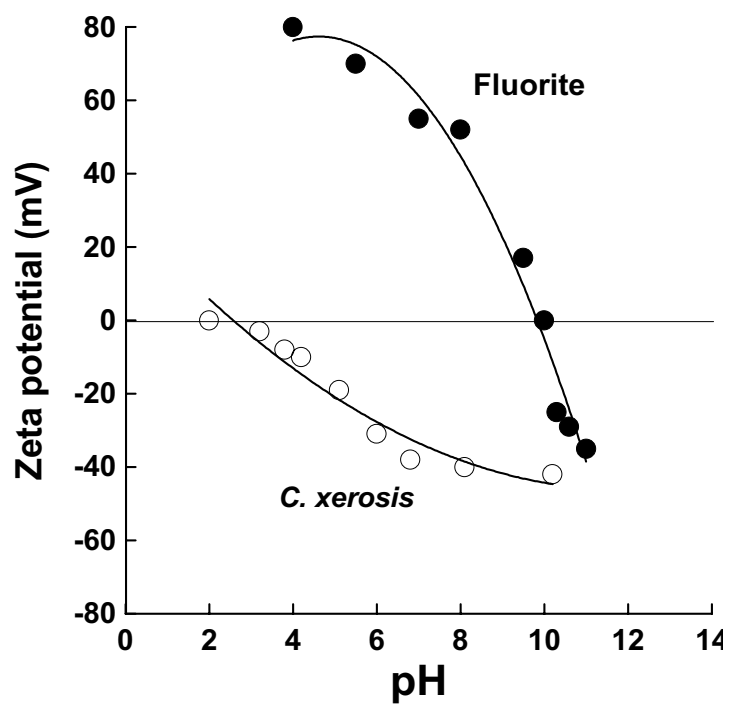

Figure 6. Zeta potential of Corynebacterium xerosis cells and fluorite particles as a function of $\mathrm{pH}$. Ionic strength mantained by addition of $1 \times 10^{-3} \mathrm{M} \mathrm{NaNO}_{3}$. 
a similar size to the particles (6). In the present case, the median size of the particles was $12.5 \mu \mathrm{m}$ and only $2 \%$ of the fluorite has a particle size smaller than $1 \mu \mathrm{m}$ (approximate size of C. xerosis cells).

In many cases, the adherence of a microorganism to a mineral surface can be predicted by a calculation based on the Derjaguin-Landau-Verwey-Overbeek (DLVO) theory $(6,18,19)$. According to this theory, the total long range interaction $(>1 \mathrm{~nm})$ between surfaces is a summation of van der Waals and coulombic interactions $(1,4)$. This theory explains the optimum flocculation behavior at neutral $\mathrm{pH}$ values in the fluorite - C. xerosis system. At $\mathrm{pH} 7.0$ the fluorite has a high positive charge (about +60 $\mathrm{mV}$ ) and the bacteria a high negative charge (about $30 \mathrm{mV}$ ).

However, a specific adsorption interaction should not be neglected. Bacteria having similar electrokinetic behavior were not able to promote the same degree of flocculation of fluorite (8). It has been shown that some Gram-negative bacteria have specific adsorption mechanisms to solid surfaces, associated with the surface lipopolysaccharides (3), and it is possible that a similar type of interaction may occur with this Gram-positive organism. Gram negative bacteria tested by us had no effect on settling (results not shown). However, the members of the Acintomycetaceae have previously been shown to promote flocculation of fine particles (5) and one possibility is that this is due to the distinctive nature of their cell wall material (11). In addition, the Corynebacterium group can produce short chains of cells because of incomplete separation after cell division (2) and this leads to a pseudo-polymeric structure, promoting cell bridging.

The concentration of $C$. xerosis required to flocculate fine fluorite suspensions is lower than that of other microorganisms reported in the literature. For instance, flocculation of hematite suspensions with the yeast Candida parapsilosis requires about $50 \mathrm{~kg} / \mathrm{t}$ of bioflocculant (12), while flocculation of fluorite with $C$. xerosis is possible with only $4 \mathrm{~kg} / \mathrm{t}$. However, the dosage required is still higher than that used in flocculation with long synthetic polymers. A long chain polyacrylamide (average molecular weight $1 \times 10^{6}$ ) flocculates some suspensions at concentrations below $0.1 \mathrm{~kg} / \mathrm{t}$.

Microorganisms are potential low cost flocculants for solid-liquid operations in mineral processing. Further studies are necessary to increase their competitiveness with common flocculants used in the mining industry. These will include research to identify more bacterial strains able to adhere to mineral surfaces, investigate the mechanisms involved, develop procedures to isolate the biochemical fraction responsible for flocculation, and to optimize the production of the bioflocculants on large scale.

\section{ACKNOWLEDGMENTS}

The authors wish to acknowledge the financial support provided by following Brazilian institutions: FAPERGS (process 96/1789.5), CNPq (process 521968/96-8).

\section{RESUMO}

\section{Floculação de partículas finas de fluorita com a Corynebacterium xerosis}

O tratamento de partículas finas dispersas em líquidos é comum em diversas indústrias e especialmente importante no processamento de minérios. A eficiência de operações de sedimentação pode ser substancialmente aumentada com a floculação. O objetivo deste trabalho foi estudar a floculação de partículas de fluorita com a bactéria Corynebacterium xerosis. A metodologia empregada para avaliar a floculação incluiu experimentos de floculação, microeletroforese e microscopia ótica. Os resultados demonstraram que as células da Corynebacterium xerosis se aderem na superfície da fluorita, promovendo a agregação das partículas. Flocos de alta qualidade podem ser obtidos rapidamente em $\mathrm{pH}$ 7,0 a uma concentração de microrganismos de $40 \mathrm{mg} / 1$, dosagem esta consideravelmente menor do que aquelas previamente relatadas na literatura. Os resultados são discutidos em termos das propriedades superficiais do mineral e do microrganismo.

Palavras-chave: adesão, Corynebacterium xerosis, floculação, fluorita.

\section{REFERENCES}

1. Adamson, A. W. Physical chemistry of surfaces. New York, John Wiley \& Sons Inc., 1990.

2. Atlas, R. M. Principles of Microbiology. Dubuque: Wm. C. Brown Publishers, 1997.

3. Beech, I.B.; Gaylarde, C.C. Adhesion of Desulfovibrio desulfuricans and Pseudomonas fluorescens to mild steel surfaces. J. Appl. Bacteriol., 67: 201-207, 1989. 
4. Characklis, W.G.; Marshall, K.C. In: Biofilms. New York, John Wiley \& Sons Inc., 1990, p. 348-349.

5. Deshpande, H.A. Microbe-manganese interactions in ironmanganese mining areas in India. In: Karavaiko, G.I.; Rossi, G.; Avakayan, Z.A. (eds.). Biohydrometallurgy. Moscow, Centre for International Projects, USSR State Committee for Environmental Protection, 1990, p. 312-319.

6. Daniels, S.L. Mechanisms involved in sorption of microorganisms to solid surfaces. In: Britton, G.; Marshall, K.C (eds.). Adsorption of Microorganisms to Surfaces. London, John Wiley and Sons, 1980, p.7-58.

7. Dübel, J.; Smith, R.W.; Misra, M.; Chen, S. Microorganisms as chemical reagents: the hematite system. Min. Eng., 5: 574556, 1992.

8. Haas, S.R.; Schneider, I.A.H. Seleção de bactérias para a floculação de finos de fluorita. II Encontro Nacional de Microbiologia Aplicada ao Meio Ambiente, Florianópolis, 1998. In press.

9. Hunter, R.J. Zeta potential in colloid science. London, Academic Press, 1981.

10. Kitchener, J.A. Flocculation in mineral processing. In: Ives, K.J. (ed.). The scientific basis of flocculation. Alphen aan den Rijn, Netherlands, 1978, p.283-328.

11. Poindexter, J.S. Microbiology - an introduction to protists. New York, MacMillan, 1971. p. 194.

12. Schneider, I.A.H.; Misra, M.; Smith, R.W. Bioflocculation of hematite suspensions with products from yeast cell rupture. Devel. Chem. Eng. Min. Process., 4: 248-252, 1994.
13. Schneider, I.A.H.; Misra, M.; Smith, R.W. Bioflocculation of fine mineral suspensions by Candida parapsilosis and its sonication products. In: Reagents for Better Metallurgy. SME, 1994, 293-301.

14. Smith, R.W.; Misra, M. Bacterial flocculation of phosphate wastes using a hydrophobic bacterium. In: Smith R.W.; Misra, M. (eds.). Minerals bioprocessing, Warrendale, TMS, 1991, p.747-756.

15. Smith, R.W. Liquid and Solid Wastes from Mineral Processing Plants. Min.Proc. Extrac. Metall. Rev., 16: 1-22, 1996.

16. Somasundaran, P. Principles of flocculation, dispersion, and selective flocculation. In: Somasundaran, P. (ed.). Fine particles processing. New York, AIME, 1980, p.947-976.

17. van Loosdrecht, M.C.M.; Lyklema, J.; Norde, W.; Schraa G.; Zehnder, A.J.B. The role of bacterial cell wall hydrophobicity in adhesion. Appl. Environ. Microbiol., 53: 1893-1897, 1987.

18. van Loosdrecht, M.C.M.; Lyklema, J.; Norde, W.; Schraa, G; Zehnder, A.J.B. Electrophoretic mobility and hydrophobicity as a measure to predict the initial steps of bacterial adhesion. Appl. Environ. Microbiol., 53:1898-1901, 1987.

19. van Loosdrech, M.C.M.; Lyklema, J.; Norde, W.; Zehnder A.J.B. Bacterial adhesion: a physicochemical approach. Microb. Ecol., 17:1-15, 1989. 